\title{
Repatriacja Polaków z Luksemburga po II wojnie światowej
}

Pierwsze grupy Polaków znalazły się w Luksemburgu już pod koniec XIX w. Po I wojnie światowej państwo to było celem emigracji zarobkowej Polonii westfalsko-nadreńskiej. W latach 30. XX w. do Luksemburga udawali się również Polacy z kraju, gdzie na miejscu dostawali zatrudnienie $\mathrm{w}$ rolnictwie lub rzadziej w górnictwie. W czasach II wojny światowej liczba Polonii luksemburskiej poważnie spadła. Pojawiła się jednak niewielka grupa robotników przymusowych, skierowanych do pracy przez Niemców. Po zakończeniu wojny, europejskie rządy przystąpiły do akcji repatriacyjnej swych obywateli. Z inicjatywą wystąpiły władze Luksemburga, które zaproponowały Warszawie układ o wzajemnej repatriacji. Takowy został podpisany 24 VIII 1945 r. W powrocie do Polski zainteresowani byli głównie robotnicy przymusowi oraz „dipisi”. Grupy te borykały się z niezwykle trudną sytuacją socjalno-bytową. Stara przedwojenna emigracja zarobkowa zdążyła się już wtopić w otoczenie. Mimo słabej organizacji aparatu repatriacyjnego ze strony władz warszawskich, do Polski repatriowało się co najmniej 334 Polaków, głównie przez Belgię.

Słowa kluczowe: Luksemburg, Benelux, repatriacja Polaków z Zachodu, ruchy migracyjne po II wojnie światowej, Polonia w Beneluksie.

\section{Repatriation of Poles from Luxembourg after Second World War}

The first waves of Polish emigrants arrived in Luxembourg at the end of 19th century. After the end of the First World War this country had become a destination of economic migration for Polish people living in the Rhine-Westphalia region. In the 1930s Poles were also leaving their country and heading for Luxembourg. There they were often employed in the agricultural sector and less commonly in the mining industry. During the Second World War the amount

\footnotetext{
${ }^{1}$ Kontakt: banc3@wp.pl
} 
of Polish people in Luxembourg considerably decreased. However, there also appeared a small group of civilians who had previously been subject to forced labor for Germans. After the end of the war European governments started the process of repatriation of their citizens. The Luxembourg Authorities initiated the creation of a mutual agreement with Poland on the subject of repatriation. This document was signed on $24^{\text {th }}$ of August 1945. Forced workers and 'DPs' were mostly interested in coming back to Poland. These groups were struggling with a deeply difficult social-economic situation. The previous migration wave which had appeared before the Second World War had already assimilated into the local society. Despite the poor organization of the repatriation machinery of the Polish Government, there were at least 334 people who successfully repatriated to Poland, usually through Belgium.

Keywords: Luxembourg, Benelux, repatriation of Poles from the West, migrations after the Second World War, Polish diaspora in Benelux.

\section{Wprowadzenie}

Masowe migracje ludności w XX w. stanowią jedną z najważniejszych kart w najnowszej historii ludzkości. Wielkie przemieszenia miały miejsce również w przeszłości, jednak specyfika migracji XX-wiecznych odróżnia je znacznie od poprzednich. Wynika to z charakterystycznych i poważnych zmian, jakie nastąpiły w ciągu ostatnich stu lat. Migracje jako zjawisko społeczne jest zawsze konsekwencją głębokich procesów ekonomiczno-społecznych lub polityczno-ideologicznych.

Ruchy ludnościowe po II wojnie światowej odróżniały się od tych XIX-wiecznych organizacją i masowością oraz stosunkowo krótkim okresem czasowym. Ich główną przyczyną były motywy polityczno-ideologiczne, z naciskiem na te pierwsze. Dotychczas, poza nieznacznymi wyjątkami, generalnym determinantem była sytuacja ekonomiczna. Polityczne decyzje, podejmowane przez wąskie grono osób, powodowały, że migrant stawał się „przedmiotem”, podporządkowanym ich polityce, co stawiało go w pozycji przymusowej. Nie oznacza to jednak, że wszystkie kategorie migrantów zostały całkowicie pozbawione swobody decydowania o swym losie. Decyzje polityczne podejmowane wobec ludności kwalifikowanej do przesiedlenia zależały od jej narodowości czy miejsca zamieszkania. Tak więc powojenna sytuacja Niemców, Polaków czy żołnierzy sił alianckich nie była jednakowa².

Po zakończeniu II wojny światowej repatriacja stała się jednym z najważniejszych problemów wielu państw europejskich. Wynikało to z masowych przemieszczeń ludności, spowodowanych działaniami wojennymi, okupacją oraz polityką narodowościową hitlerowskich Niemiec. Sprawność przeprowadzenia repatriacji był wyznacznikiem siły organizacji danego rządu. Przed tym zadaniem stanęła również Polska, która ponadto musiała odbudować swą administrację, gospodarkę oraz

${ }^{2}$ K. Kersten (1974), Repatriacja ludności polskiej po II wojnie światowej. Studium historyczne, Wrocław: Zakład Narodowy im. Ossolińskich, Wydawnictwo PAN, s. 3-4. 
całość życia zbiorowego po latach okupacji. Skala repatriacji Polaków była jednak znacznie większa niż innych narodowości, co wiązało się z masowymi przymusowymi wywózkami z lat 1939-1944 oraz całkowicie zmienionymi granicami kraju. Utracenie Kresów Wschodnich oraz uzyskanie Ziem Odzyskanych skutkowało przeprowadzeniem przesiedleń w celu zaludnienia Ziem Zachodnich żywiołem polskim, znajdującym się w 1945 r. poza nowymi granicami państwa.

Repatriacja pozwalała przywrócić krajowi miliony obywateli rozsianych po całym świecie. Byli oni niezbędni podczas szybkiej odbudowy wszystkich sfer życia społecznego w państwie. Poza granicami znalazło się wielu ludzi młodych, obdarzonych sprytem i zaradnością. Szczególnie liczono jednak na wykwalifikowane siły robotnicze oraz inteligencję, która poniosła poważne straty w czasie okupacji. Polacy, którzy znaleźli się na Zachodzie, byli mobilni, przywykli do życia w nowych warunkach. Stawali się przez to znakomitym materiałem do zaludnienia Ziem Odzyskanych, gdzie należało od podstaw i w krótkim czasie stworzyć całość życia społeczno-politycznego w ramach państwa polskiego ${ }^{3}$.

W trakcie pracy nad niniejszym artykułem autor przeanalizował, nieliczne zresztą, opracowania poświęcone Polakom w Luksemburgu. Prace te powstawały na przestrzeni ostatniego wieku. Należało wziąć pod uwagę uwarunkowania oraz okoliczności, w jakich one powstały, tak aby nie dać się zwieść pozanaukowym intencjom ich autorów. Generalnie rzecz biorąc, te nieliczne opracowania pozwoliły zarysować szablon genezy powstania polskiej społeczności w Luksemburgu oraz jej funkcjonowania do zakończenia II wojny światowej. Element ten był niezbędny, jednak nie był głównym problemem badanym przez autora, którego celem było skupienie się na okolicznościach samej repatriacji. To zagadnienie nie miało już niemal żadnego odzwierciedlenia w opracowaniach. Aby wyjaśnić ten wątek autor musiał skorzystać ze źródeł dokumentowych, które znajdowały się w różnych zespołach archiwalnych. Na początku konieczne okazało się ustalenie, choć przybliżonej, liczby Polaków w Luksemburgu w chwili wyzwolenia tego państwa. W jej oszacowaniu pomocne stały się materiały resortów polskiego rządu w Londynie. Sama zaś akcja repatriacyjna teoretycznie winna być odwzorowana na podstawie materiałów z zespołu Generalnego Pełnomocnika Rządu do spraw Repatriacji. Ten jednak poza umową repatriacyjną nie udostępnia żadnych innych dokumentów. Kluczem do odtworzenia procesu powrotu Polaków z Luksemburga okazały się zasoby Archiwum Ministerstwa Spraw Zagranicznych, jednak w materiałach poświęconych nie tyle samemu Luksemburgowi, co Belgii. Dopiero analiza tych dokumentów pozwoliła na oszacowanie przybliżonej liczby powrotów do Polski. Trudności te wynikały z marginalnego znaczenia repatriacji z Luksemburga w całym powojennym procesie migracyjnym Polonii.

${ }^{3}$ J. Wróbel (2009), Na rozdrożu historii. Repatriacja obywateli polskich z Zachodu $w$ latach 1945-1949, Łódź: Instytut Pamięci Narodowej, s. 9-14. 


\section{Polonia w Luksemburgu do końca II wojny światowej}

Pierwsze grupy Polaków w Luksemburgu znalazły się na przełomie XIX i XX w. Byli to głównie robotnicy przemysłowi wywodzący się z zaboru pruskiego, przede wszystkim z Poznańskiego, a także z Galicji. Znaleźli oni pracę w kopalniach i hutach żelaza oraz w przemyśle metalurgicznym.

Na większą skalę Polacy zaczęli emigrować do Luksemburga po zakończeniu I wojny światowej, jednak dotyczyło to tylko społeczności polskiej z Westfalii i Nadrenii, skąd przybywali górnicy i robotnicy przemysłowi. Było to spowodowane złą sytuacją gospodarczą Niemiec, ale przede wszystkim był to rezultat akcji opcyjnej. Po zakończeniu wojny Polacy przebywający w Niemczech poddani zostali prawu opcji, polegającemu na zdefiniowaniu, czy jest się Polakiem, czy też Niemcem. Ci, którzy wybrali pierwszą opcję, zmuszeni zostali do opuszczenia Niemiec. Wobec złej sytuacji gospodarczej odrodzonej Polski część z nich wolała udać się do krajów Beneluxu lub do Francji. W okresie dwudziestolecia międzywojennego przybywali również do Luksemburga polscy robotnicy z Belgii i Francji, choć najczęściej nielegalnie. Ci również kierowali się chęcią poprawy swych warunków bytowych, które były znaczne lepsze niż w Belgii czy Francji ${ }^{4}$. W połowie lat dwudziestych liczbę przebywających w Luksemburgu Polaków szacowano na ok. 5 tys. osób ${ }^{5}$. Jednak w niedługim czasie połowa $\mathrm{z}$ nich opuściła to małe księstwo i przeniosła się do Belgii lub Francji 6 .

Mimo zmiennej koniunktury gospodarczej w Luksemburgu liczba Polaków w tym państwie utrzymywała się na względnym poziomie. Polscy emigranci zarobkowi nie byli wyjątkiem w Luksemburgu. Państwo to charakteryzował niski przyrost naturalny, a jednocześnie duża chłonność imigrantów z wielu krajów Europy. W 1930 r. aż 18,6\% ludności kraju stanowili cudzoziemcy ${ }^{7}$. Polacy w tym małym księstwie uzyskiwali zatrudnienie przeważnie w przemyśle. Ich głównym skupiskiem był region miasta Esch-sur-Alzette, gdzie skupiało się górnictwo i przemysł metalurgiczny kraju. Natomiast robotnicy rolni mieszkali przeważnie na północy państwa ${ }^{8}$.

W latach 1918-1926 Luksemburg nie był celem polskiej emigracji zarobkowej. Sytuacja zmieniła się w II poł. lat 20., kiedy to odnotowano pierwsze wyjazdy do tego państwa. Gwałtowny spadek liczby emigrujących Polaków do Luksemburga

${ }^{4}$ W. Eder (1992), Polonia w krajach Beneluksu. Luksemburg, w: Szydłowska-Ceglowa B. (red.), Polonia w Europie, Poznań: Polska Akademia Nauk. Zakład Badań Narodowościowych, s. 516.

${ }^{5}$ E. Basiński (1971), Polonia solidarna z Macierza. Z dziejów wychodźstwa polskiego, Warszawa: Ludowa Spółdzielnia Wydawnicza, s. 197.

${ }^{6}$ W. Eder (1988), Z dziejów wychodźstwa polskiego do Luksemburga, „Przegląd Polonijny”, z. 4 , s. 85 .

7 Idem, Polonia..., s. 516.

8 J. Wróbel, op. cit., s. 31. 
nastąpił w I poł. lat 30., co wynikało z kryzysu gospodarczego, który dotknął również to księstwo. Liczba emigrujących ze 120 osób w 1930 r. spadła do zaledwie 3 osób w 1936 r. Było to również spowodowane zaostrzeniem polityki imigracyjnej Luksemburga, gdzie od 1932 r. odsyłano wielu obcokrajowców, w tym Polaków, do krajów macierzystych. Sytuacja uległa zmianie dopiero w 1937 r., kiedy to do Luksemburga wyjechało aż 870 osób. Ogółem w latach 1926-1938 z Polski do Luksemburga wyjechały 1384 osoby, powróciły zaś $274^{9}$.

Tabela 1 .

Emigracja Polaków z Polski do Luksemburga w dwudziestoleciu międzywojennym

\begin{tabular}{|c|c|c|c|c|}
\hline Okres & $1918-1925$ & $1926-1931$ & $1932-1936$ & $1937-1938$ \\
\hline Liczba imigrantów & 0 & 173 & 23 & 1188 \\
\hline
\end{tabular}

Źródło: AAN, MSZ, sygn. 9886, Dr Zarychta Apoloniusz. Dwudziestolecie emigracji z Polski 1918-1938. Wychodźstwo do krajów Europy [maszynopis], k. 136.

Tabela 2 .

Powroty Polaków z Luksemburga do Polski w dwudziestoleciu międzywojennym

\begin{tabular}{|c|c|c|c|c|}
\hline Okres & $1918-1925$ & $1926-1931$ & $1932-1936$ & $1937-1938$ \\
\hline Liczba imigrantów & 0 & 50 & 34 & 190 \\
\hline
\end{tabular}

Źródło: AAN, MSZ, sygn. 9886, Dr Zarychta Apoloniusz. Dwudziestolecie emigracji z Polski 1918-1938. Powrót wychodźców z krajów Europy [maszynopis], k. 138.

W latach 1926-1938 emigracja z Polski do Luksemburga stanowiła zaledwie 0,35\% polskiego wychodźstwa do krajów europejskich i rekrutowała się głównie z Wielkopolski i Małopolski. Wiązało się to m.in. ze znacznym przeludnieniem niektórych terenów II RP. Emigranci ci zajmowali się w Luksemburgu głównie uprawą roli. Polacy byli chętnie zatrudniani w tym państwie jako robotnicy rolni od połowy lat 30., kiedy to restrykcyjne przepisy wprowadzone przez Berlin i Rzym zmusiły wielu Niemców i Włochów do powrotu do swych krajów. Jak

9 Archiwum Akt Nowych (dalej AAN), Ministerstwo Spraw Zagranicznych (dalej MSZ), sygn. 9886, Dr Zarychta Apoloniusz. Dwudziestolecie emigracji z Polski 1918-1938. Wychodźstwo do krajów Europy [maszynopis], k. 136; ibidem, Dr Zarychta Apoloniusz. Dwudziestolecie emigracji z Polski 1918-1938. Powrót wychodźców z krajów Europy [maszynopis], k. 138. Wiesława Eder niesłusznie podaje, iż nie zachowały się statystyki emigracji Polaków do Luksemburga za okres do 1930 r.; confer: W. Eder, Polonia..., s. 517-518. Więcej na temat emigracji zarobkowej w II RP, vide: H. Janowska (1981), Emigracja zarobkowa z Polski 1918-1938, Warszawa: Państwowe Wydawnictwo Naukowe, passim. 
dotąd byli oni najliczniejszymi grupami narodowymi zatrudnionymi w luksemburskim rolnictwie i w momencie ich reemigracji wytworzyła się znaczna pustka na rynku pracy ${ }^{10}$.

W momencie wybuchu II wojny światowej (1939 r.) w Luksemburgu przebywało ok. 3,75 tys. Polaków ${ }^{11}$. Już w październiku 1939 r. do kraju próbowało przedostać się ok. $200 \mathrm{z}$ nich, jednak wielu zostało zatrzymanych na terenie Niemiec i skierowanych do robót przymusowych ${ }^{12}$. Część Polonii luksemburskiej zasiliła armię polską na Zachodzie ${ }^{13}$. Według niemieckich danych z 15 XII 1940 r. na terenie okupowanego księstwa znajdowało się 1023 Polaków i 135 polskich Żydów. Pod koniec 1941 r. liczba ta spadła do 779 osób. W następnym roku ludność żydowską wywieziono do niemieckich obozów zagłady ${ }^{14}$.

W tym czasie na terenie okupowanego księstwa znajdowali się polscy robotnicy przymusowi, skierowani tu przez Niemców. Poselstwo rządu emigracyjnego w Brukseli wyliczyło, że w listopadzie 1944 r. na terenie księstwa przebywało ok. 100 Polaków, będących wcześniej robotnikami przymusowymi ${ }^{15}$. Spis wszystkich obcokrajowców, którzy znaleźli się w Luksemburgu po 1940 r., został opracowany do stycznia $1945 \mathrm{r}$. Wynikało z niego, że w państwie tym znajdują się dokładnie 102 „dipisi” ${ }^{\prime 16}$ narodowości polskiej ${ }^{17}$.

Spośród tej grupy 65 osób przebywało w ośrodkach dla „dipisów”, zlokalizowanych w stolicy kraju, jej okolicach oraz w pobliżu miasta Esch-sur-Alzette. Warunki, w jakich przebywali, były znośne. Dużym jednak problemem było to, że Polacy zostali umieszczeni razem z ludnością z ZSRR, co wywoływało wzajemne tarcia. Poselstwo polskie w Brukseli zabiegało u władz luksemburskich o osadzenie wszystkich Polaków w jednym ośrodku, co miało poprawić ich warunki bytowe oraz bezpieczeństwo. Istniały bowiem liczne przypadki, że Polacy byli wykorzystywani

${ }^{10}$ F. Loesch (1937), Emigracja polska w Wielkim Księstwie Luksemburskim, „Polacy Zagranicą”, nr 11, s. 34

11 AAN, MSZ, sygn. 9886, Dr Zarychta Apoloniusz. Dwudziestolecie emigracji z Polski 19181938. Rozmieszczenie Polaków 1939 [maszynopis], k. 58.

${ }^{12}$ Więcej na temat niemieckich wysyłek Polaków na roboty przymusowe vide: Cz. Łuczak (1979), Polityka ludnościowa i ekonomiczna hitlerowskich Niemiec w okupowanej Polsce, Poznań: Wydawnictwo Poznańskie, passim.

13 B. Wierzbiański (1946), Polacy w świecie, Londyn: Światpol, s. 234-236, Idem (1946), Polonia zagraniczna w latach 1939-1946, Londyn: Światowy Związek Polaków z Zagranicy, s. 56-58.

${ }^{14}$ S. Zabraniak (2006), Polacy w Luksemburgu. Imigracja i duszpasterstwo w XX wieku, „Studia Polonijne", t. 27, s. 165.

15 AAN, Ministerstwo Pracy i Opieki Społecznej w Londynie (dalej MPiOS w Londynie), sygn. 120, Poselstwo polskie w Brukseli do MSZ w Londynie [21 XI 1944], k. 1.

${ }^{16}$ Dipisi - od ang. Displaced Persons, w skrócie DPs - osoby, które w wyniku wojny znalazły się poza terenem swojego państwa i przebywały tam mimo zakończenia działań zbrojnych, nie mając możliwości samodzielnego powrotu do ojczyzny.

17 AAN, Generalny Pełnomocnik Rządu do Spraw Repatriacji (dalej GPRdSR), sygn. 456, Displaced Poles [8 VI 1945 r.], k. 189. 
do robót rolnych przez miejscowych, świadomych tego, że Polacy nie posiadają żadnych środków do przeżycia ${ }^{18}$.

Anastazy Nadolny szacuje, że w latach 1945-1946 na terenie Luksemburga mogło znajdować się ok. 2-3 tys. Polaków ${ }^{19}$, przy czym liczba ta obejmuje również „dipisów”. Suma ta wydaje się jednak zawyżona. Emigracyjne Ministerstwo Przemysłu, Handlu i Żeglugi posiadało dane mówiące, iż po wyzwoleniu Luksemburga w 1944 r. na jego terenie znajdowało się łącznie ok. 2 tys. Polaków, nie licząc wojska ${ }^{20}$. Liczba ta obejmuje również przedwojenną Polonię zamieszkałą w księstwie.

Zaznaczyć należy, że zainteresowanie powrotem do Polski, oprócz byłych robotników przymusowych oraz polskich jeńców z Wehrmachtu przebywających wówczas w Luksemburgu, było wśród Polaków niewielkie. „Dipisi” pragnęli powrotu wskutek ich ciężkiej sytuacji bytowej. Nie posiadali oni żadnych środków materialnych, a mieszkali najczęściej w ośrodkach dla uchodźców. Liczne były przypadki niechęci Luksemburczyków do polskich „dipisów” lub ich wykorzystywanie do półdarmowej pracy ${ }^{21}$. Jednak większość przebywających wówczas w Luksemburgu Polaków stanowiła przedwojenna emigracja zarobkowa, która nie była zainteresowana powrotem do kraju. Posiadali oni dobre pensje, warunki socjalno-bytowe oraz zdążyli wtopić się w lokalną społeczność, zawierając małżeństwa mieszane. Niektórzy spośród osób, które nie chciały powrócić do kraju, kierowali się brakiem akceptacji dla nowej władzy i ustroju w Polsce. Ich liczbę oceniano na kilkadziesiąt osób ${ }^{22}$.

Po zakończeniu działań wojennych na terenie Luksemburga znalazło się przejściowo kilka tysięcy „dipisów”, a wśród nich ok. 600 Polaków ${ }^{23}$. Liczba ta jest jedynie orientacyjna ze względu na ciągłe, samoczynne ruchy ludności po wyzwoleniu zachodniej Europy. Najprawdopodobniej jest to liczba wszystkich polskich „dipisów”, którzy znaleźli się w Księstwie na dłuższy lub krótszy okres, od jesieni 1944 r. do końca 1945 r. Początkowo polscy uchodźcy przybywali do tego księstwa nielegalnie i w sposób niezorganizowany. Część z nich repatriowała się do kraju przez polską Misję Repatriacyjną w Luksemburgu lub w Belgii czy Francji. Część jednak nie chciała wracać do Polski. Dopiero w 1949 r. władze tego państwa zawarły umowę z Międzynarodową Organizacją ds. Uchodźców, na podstawie której

18 AAN, MPiOS w Londynie, sygn. 120, Poselstwo polskie w Brukseli do MSZ w Londynie, k. 1-5.

19 A. Nadolny (1984), Polonia w Luksemburgu (1918-1985), „Studia Polonijne”, t. 8, s. 110.

20 AAN, Ministerstwo Przemysłu, Handlu i Żeglugi w Londynie, sygn. 382a, Summary table of displaced persons, k. 196; confer: K. Kersten, op. cit., s. 62.

${ }^{21}$ AAN, MPiOS w Londynie, sygn. 120, List Janiny Niżyńskiej do ambasadora [nie podano jakiego] [24 IV 1945], k. 24-27.

22 Archiwum Ministerstwa Spraw Zagranicznych (dalej AMSZ), Departament Polityczny 19451948 (dalej DP), sygn. z. 6, w. 76, t. 1088, Konsulat RP w Luksemburgu do poselstwa RP w Brukseli [7 V 1948 r.], k. 26.

${ }^{23}$ A. Nadolny, op. cit., s. 110; J. Wróbel, op. cit., s. 69. 
zalegalizowano pobyt części „dipisów” oraz zezwolono na przybycie kolejnych ${ }^{24}$. W wyniku tej umowy, w latach 1947-1951 zalegalizowano pobyt w Luksemburgu co najmniej 77 Polaków ${ }^{25}$. Większość „dipisów” przebywała w Luksemburgu czasowo, po czym wyjechała do Ameryki Północnej, Australii lub Wielkiej Brytanii.

\section{Akcja repatriacyjna}

Wraz z wygasaniem światowego konfliktu poszczególne państwa przystępowały do coraz bardziej zorganizowanej repatriacji swych obywateli rozsianych po całej Europie lub świecie. Władze tzw. Polski lubelskiej rozpoczęły sprowadzanie Polaków stosunkowo wcześnie, mimo że większą część kraju okupowali jeszcze Niemcy. W pierwszej kolejności przystąpiono do repatriacji Polaków z trzech radzieckich republik zachodnich, tj. Litwy, Białorusi i Ukrainy. Stosowne umowy z władzami tych republik podpisano w dniach 9 i 22 IX 1944 r. Wcześniej Polski Komitet Wyzwolenia Narodowego zrzekł się na korzyść ZSRR terenów na wschód od Bugu. Ewakuacja Polaków z tych obszarów wiązała się zarówno z naciskami Moskwy, jak i zagrożeniem wynikającym z grasowania band Ukraińskiej Powstańczej Armii, dopuszczającej się licznych mordów na polskich cywilach.

Jednak do szerokiej akcji repatriacyjnej, obejmującej rodaków z całego świata, można było przystąpić dopiero po usunięciu Niemców z całości państwa polskiego oraz przyznanych mu na konferencji w Jałcie Ziem Odzyskanych. Zorganizowana akcja mogła mieć jednak pełen wymiar dopiero wraz z kapitulacją Niemiec. Przerwanie walk pozwoliło wykorzystać transport kolejowy do przerzutu Polaków z Europy Zachodniej. Było to ogromne wyzwanie, bowiem w samych Niemczech szacowano ich liczbę na 1,9-2 mln osób. Początkowo jednak znaczny odsetek Polaków powracał na własną rękę. Dopiero latem 1945 r. przystąpiono do repatriacji Polaków ze strefy radzieckiej, natomiast z pozostałych stref - jesienią. Przypuszcza się, że do końca 1949 r. repatriowano z Niemiec do Polski ponad 1,5 mln osób ${ }^{26}$.

Duże skupiska osób narodowości polskiej znajdowały się również w innych krajach Europy Zachodniej i świata. Krystyna Kersten szacowała ich liczbę na ok. 0,5 mln osób ${ }^{27}$. Część spośród nich również powróciła samodzielnie zaraz po zakończeniu działań wojennych. Dotyczyło to najczęściej byłych robotników przymusowych, pozbawionych niejednokrotnie podstawowych środków do życia. $\mathrm{W}$ drugiej połowie $1945 \mathrm{r}$. rząd polski podpisał szereg umów repatriacyjnych z różnymi państwami europejskimi. W ich wyniku powołane zostały misje repatriacyjne,

${ }^{24}$ W. Eder, Polonia..., s. 522.

${ }^{25}$ K. Kersten, op. cit., s. 250.

${ }^{26}$ D. Sula (2002), Działalność przesiedleńczo-repatriacyjna Państwowego Urzędu Repatriacyjnego w latach 1944-1951, Lublin: Wydawnictwo Katolickiego Uniwersytetu Lubelskiego, s. 146-147.

${ }_{27}$ Bez Niemiec i ZSRR. 
stacjonujące na terenie państwa drugiego, których celem było prowadzenie samej akcji. Początkowo takowe znajdywały się tylko w krajach o dużych skupiskach Polaków, jak: Francja, Włochy, Czechosłowacja, Wielka Brytania, Jugosławia czy Belgia. Rozbudowa polskiego aparatu repatriacyjnego pozwoliła jednak na podpisywanie umów oraz wysyłanie misji również do innych państw. Oprócz przymusowych robotników, wywiezionych na Zachód przez Niemców, władze szczególnie zabiegały o powrót do Polski przedwojennej emigracji zarobkowej. Ta grupa Polonii charakteryzowała się najczęściej dobrą sytuacją finansowo-materialną oraz wysokimi kwalifikacjami zawodowymi. Liczono, że ich powrót ułatwi i przyśpieszy odbudowę kraju oraz zagospodarowanie Ziem Odzyskanych.

Taka grupa przedwojennych emigrantów znajdowała się w Luksemburgu. Jednak to nie od strony polskiej wyszła inicjatywa uregulowania wzajemnych spraw ludnościowych. W dniu 24 VIII 1945 r. do polskiej ambasady w Paryżu zwrócili się przedstawiciele ambasady Luksemburga z propozycją złożenia wizyty w Warszawie przez luksemburskiego szefa spraw zagranicznych Josepha Becha. Głównym celem wizyty miało być omówienie spraw repatriacji do Luksemburga jego obywateli, przebywających dalej na terenie Polski. Ponadto J. Bech miał przybyć w towarzystwie René Bluma, posła Luksemburga w Moskwie, który to miał również złożyć listy uwierzytelniające w Warszawie ${ }^{28}$. Ze swej strony ambasada polska w Paryżu poparła luksemburską inicjatywę, zaznaczając, że wizyta w Warszawie szefa dyplomacji tego państwa może mieć dodatkowe cele aniżeli tylko sprawy repatriacyjne ${ }^{29}$.

Wizyta odbyła się dokładnie miesiąc po wystosowaniu prośby. W dniu 24 IX 1945 r. przybyli do Warszawy minister spraw zagranicznych Luksemburga J. Bech wraz z posłem nadzwyczajnym i ministrem pełnomocnym R. Blumem oraz szefem luksemburskiej Komisji Repatriacyjnej Josephem Kaufmanem. Delegacja została przyjęta przez wiceministra spraw zagranicznych Zygmunta Modzelewskiego. Podpisano wówczas umowę o wzajemnej repatriacji obywateli polskich znajdujących się w Luksemburgu, jak również luksemburskich w Polsce. Rozciągała się ona zarówno na osoby, które znalazły się w Polsce lub Luksemburgu wskutek działań niemieckich, jak i na te, które przebywały w tych państwach lub czasowo zamierzały się do nich udać już po zakończeniu działań wojennych. Oznaczało to, że układające się państwa zobowiązywały się zezwalać na tranzyt obywateli drugiej strony umowy z obszarów państw trzecich. Przykładowo Luksemburg miał przyjmować Polaków m.in. z Francji i Zachodnich Niemiec, a Polska Luksemburczyków m.in. z ZSRR. Zdawano sobie jednak sprawę, że powyższy zapis musi być traktowany w granicach zdrowego rozsądku, ze względu na dysproporcje liczbowe w rozmieszczeniu Polaków na zachodzie i Luksemburczyków na wschodzie Europy oraz potencjały

${ }^{28}$ AMSZ, DP, sygn. z. 6, w. 76, t. 1083, Grand-Duché de Luxembourg Legation de Paris do ambasady polskiej w Paryżu [24 VIII 1945 r.], k. 2-3.

29 AMSZ, DP, sygn. z. 6, w. 76, t. 1083, A. Beckier do MSZ [29 VIII 1945 r.], k. 1. 
posiadane przez oba państwa. Do czasu repatriacji obywatele obu państw mieli być równorzędnie traktowani na obszarze każdego z tych państw.

Układające się strony zobligowały się do powołania misji repatriacyjnych i delegowania ich na teren drugiego państwa. Misje te miały się zajmować całością procesu repatriacyjnego oraz roztaczać opiekę nad repatriantami. W razie wątpliwości miały się wzajemnie kontaktować. Ponadto do zadań tych placówek należało sporządzenie listy osób z pierwszeństwem repatriacji, a więc małoletnich, chorych, starców, kobiet oraz osób posiadających już rodziny w państwie macierzystym. Umowa miała obowiązywać przez trzy miesiące, ale ulegała automatycznie przedłużeniu, jeżeli nie została na miesiąc przed końcem terminu wypowiedziana przez którąś ze stron ${ }^{30}$.

Do umowy dołączony został protokół dodatkowy regulujący kilka kwestii. Obie misje repatriacyjne miały wymienić się posiadanym materiałem dokumentacyjnym odnośnie do możliwości przebywania na swym terytorium osób narodowości drugiej strony. Miało to ułatwić poszukiwania ludzi zainteresowanych powrotem do swojej ojczyzny. Ponadto obydwie strony zobowiązały się do ułatwienia repatriantom przejazdu przez swe terytorium, zapewnienia im paczek żywnościowych na okres 10 dni oraz możliwości zabrania swego dobytku ${ }^{31}$. Władze Luksemburga zobowiązały się do transportu repatriantów oraz ich mienia na własny koszt do portu w Antwerpii lub innego miejsca, skąd dalej mogliby się udać do Polski ${ }^{32}$.

Należy zaznaczyć, że powyższa umowa była bardzo korzystna dla Polski. Wynikało to przede wszystkim z dysproporcji liczbowej rozmieszczenia ludności luksemburskiej w Polsce i polskiej w Luksemburgu, której było znacznie więcej.

W wywiadzie prasowym wiceminister spraw zagranicznych Z. Modzelewski stwierdził, że porozumienie to ułatwi powrót do ojczyzny zarówno przedwojennej emigracji zarobkowej, o której jednak nie było mowy w układzie, jak i przymusowych robotników skierowanych do Luksemburga przez Niemców w okresie II wojny światowej. Dodał również, że umowa jednocześnie ułatwi repatriację do Luksemburga „setek obywateli” tego państwa, którzy jakoby mieli się znaleźć na terenie Polski wskutek działań niemieckich. Nowo akredytowany poseł luksemburski w Warszawie R. Blum nadmienił, że do luksemburskiego Komitetu Repatriacyjnego już zgłaszają się Polacy zarówno z Księstwa, jak i z pobliskich rejonów Francji i Belgii $^{33}$. Wspomniana w układzie misja repatriacyjna została wysłana do Luksemburga w drugiej połowie października 1945 r. Na jej czele stanął kpt. Koźluk ${ }^{34}$.

${ }^{30}$ AAN, GPRdSR, sygn. 403a, Umowa dwustronna między Rzeczpospolitą Polską i Wielkim Księstwem Luksemburskim dotyczaca repatriacji [obywateli] im przynależnych $i$ wysiedlonych $z$ powodu wojny [24 IX 1945], k. 1-2.

31 AAN, GPRdSR, sygn. 403a, Protokót podpisu [24 IX 1945 r.], k. 4.

32 AMSZ, DP, sygn. z. 6, w. 63, t. 828, Poselstwo RP w Brukseli do MSZ [12 II 1946 r.], k. 17.

${ }_{33}$ Podpisanie umowy repatriacyjnej polsko-luksemburskiej, „Głos Ludu” (1945), nr 253, s. 2.

${ }^{34}$ Polskie misje repatriacyjne pracują na terenie Europy Zachodniej, „Głos Ludu” (1945), nr 274, s. 4. 
W dniu 25 IX 1945 r. delegacja luksemburska przybyła do Krakowa. Goście zwiedzili zabytki miasta, Uniwersytet Jagielloński oraz niektóre przedsiębiorstwa. Słuszne okazały się domysły polskiej placówki w Paryżu, bowiem Luksemburg był zainteresowany polskimi dostawami węgla i koksu, co oficjalnie wyraził minister J. Bech. Następnego dnia delegacja udała się do Oświęcimia i Brzezinki, gdzie gościom pokazano niemiecki obóz zagłady Auschwitz-Birkenau ${ }^{35}$. Zdawano sobie bowiem sprawę, że szef luksemburskiej dyplomacji jest jednocześnie członkiem międzynarodowej organizacji badającej zbrodnie niemieckie w czasie II wojny światowej. Lustracja obozu miała na celu zwrócenie uwagi gościa na ogrom zbrodni dokonanych przez niemieckich okupantów ${ }^{36}$.

Brak jest jakichkolwiek dokumentów poświadczających zorganizowane wyjazdy Polaków z Luksemburga do Polski w okresie od października 1945 r. do marca 1946 r. Dopiero materiały dotyczące repatriacji Polaków z Belgii wspominają o transporcie kolejowym 91 Polaków z księstwa, którzy wyjechali w dniu $29 \mathrm{IV} 1946 \mathrm{r}^{37} \mathrm{~W}$ kolejnych zestawieniach zbiorczych podaje się tę liczbę jako sumę wszystkich Polaków, którzy wyjechali z Luksemburga do kwietnia 1946 r. Przyjąć więc należy, że w okresie październik 1945 r. - marzec 1946 r. nie było zorganizowanych transportów do Polski. W czerwcu tego roku wyjechało kolejnych 12 osób $^{38}$, we wrześniu 67 osób ${ }^{39} \mathrm{i}$ w październiku - 11 osób $^{40}$.

W repatriacji Polaków nie pomagała biurokracja i opieszałość polskich organów władzy oraz instytucji odpowiedzialnych za ich losy. Dopiero na początku roku 1947 konsulat RP w Luksemburgu ustalił, że wśród niemieckich jeńców wojennych przetrzymywanych na terenie księstwa przebywa co najmniej 42 Polaków ze Śląska, Pomorza i Poznańskiego, którzy zostali siłą wcieleni do Wehrmachtu. Zrodził się wówczas pomysł, aby wykorzystać luksemburski konwój samochodowy, który udawał się do Polski w celu przetransportowania zwłok poległych Luksemburczyków do ojczyzny. Konwój w drodze do Polski mógłby zabrać wspomnianych Polaków ${ }^{41}$.

${ }^{35}$ AMSZ, DP, sygn. z. 6, w. 76, t. 1083, Wizyta Ministra Spraw Zagranicznych Luksemburgu Józefa Becha i Posła Nadzwyczajnego i Ministra Petnomocnego Luksemburgu René Bluma [...] w Krakowie i Oświęcimiu [27 IX 1945 r.], k. 4-6.

36 AMSZ, DP, sygn. z. 6, w. 76, t. 1083, Wnioski na temat pobytu w Polsce Ministra Becha i Posta Blum [bd.], k. 8-9.

${ }^{37}$ AMSZ, DP, sygn. z. 6, w. 63, t. 827, Sprawozdanie z repatriacji za miesiąc kwiecień 1946 [bd.], k. 52 .

${ }^{38}$ AMSZ, DP, sygn. z. 6, w. 63, t. 827, Raport repatriacyjny za miesiac czerwiec 1946 r. [13 VII 1946 r.], k. 84.

${ }^{39}$ AMSZ, DP, sygn. z. 6, w. 63, t. 827, Raport repatriacyjny za miesiąc wrzesień 1946 [8 X 1946 r.], k. 98 .

${ }^{40}$ AMSZ, DP, sygn. z. 6, w. 63, t. 827, Raport repatriacyjny za miesiąc październik 1946 [20 XI 1946 r.], k. 84.

${ }^{41}$ AMSZ, DP, sygn. z. 6, w. 76, t. 1088, Z. Sobolewski do Państwowego Urzędu Repatriacyjnego [25 I 1947 r.], k. 21. 
Pojawiły się jednak trudności wynikające z braku pomysłu na zorganizowanie dla nich prowiantu na 3-4 dni podróży. Zastanawiano się również, czy nie przydzielić konwojowi eskorty wojskowej, skoro owi jeńcy polscy nie byli wcześniej zweryfikowani. Sprawę dodatkowo komplikowała długotrwała wymiana korespondencji pomiędzy konsulem polskim w Luksemburgu, konsulatem generalnym RP w Brukseli i poselstwem RP w tym samym mieście ${ }^{42}$.

Ostatecznie nie wykorzystano okazji, jaką mógł być transport polskich repatriantów luksemburskim konwojem i wspomniane osoby dalej pozostawały w obozach jenieckich na terenie Księstwa, mimo że Administration Militaire, odpowiedzialny za nadzór nad obozami jenieckimi w Luksemburgu, nie widział przeszkód w repatriacji do kraju tej grupy Polaków. Konsulat RP w Luksemburgu donosił jednak polskiemu poselstwu w Brukseli, że należy przystąpić czym prędzej do zorganizowania powrotu owych kilkudziesięciu Polaków, bowiem Administration Militaire w najbliższych dniach miał przystąpić do likwidacji obozów, a wszystkich ludzi w nich przetrzymywanych - odesłać do Niemiec ${ }^{43}$.

O irytacji Polaków w Luksemburgu brakiem możliwości powrotu do ojczyzny może świadczyć list Edwarda Szczuckiego do konsula generalnego Polski w Brukseli, w którym skarży się na opieszałość i lekceważenie ich problemu przez konsula w Luksemburgu. Oto fragment listu: „(...) pan Konsulat [w Luksemburgu] nas odrzuca, z miesioca na miesionc jak byśmy za głupich byli. [...] Jeżeli pan Konsulat [w Brukseli] nam w tej sprawie nic nie pomorze to jesteśmy naprawie temy głupiemi. Myśmy już dostali zdomu papiery jako jesteśmy Polacy. A pan Konsulat [w Luksemburgu] nas może tak odrzucać jak śmieci. Wiec prosimy pana Konsulata [w Brukseli] nam o jaknajprekszą odpowiedzi”"44.

Według danych konsulatu RP w Luksemburgu, w samym tylko 1947 r. powróciło z terenów księstwa do Polski 153 Polaków, w tym 27 byłych jeńców Wehrmachtu ${ }^{45}$. Oznacza to, że spośród 42 jeńców Wehrmachtu, zidentyfikowanych jako Polacy na początku 1947 r., 15 uznano za osoby niesłusznie podające się za Polaków. Inna możliwość zakłada, że byli oni autochtonami z Ziem Odzyskanych, których błędnie określono jako Niemców. Ostatecznie mogli również powrócić na własną rękę, po zwolnieniu z obozów jenieckich.

Sumując dane z 1946 r. i 1947 r., otrzymujemy łączną liczbę co najmniej 334 Polaków, którzy repatriowali się do Polski w latach 1945-1947. Należy również

${ }^{42}$ AMSZ, DP, sygn. z. 6, w. 76, t. 1088, Poselstwo RP w Brukseli do konsulatu RP w Luksemburgu [4 II 1947 r[, k. 22; ibidem, Poselstwo RP w Brukseli do konsulatu RP w Luksemburgu [11 III 1947 r.], k. 23.

${ }^{43}$ AMSZ, DP, sygn. z. 6, w. 76, t. 1088, Konsulat RP w Luksemburgu do poselstwa RP w Brukseli [14 III 1947 r.], k. 24.

${ }_{44}$ AMSZ, DP, sygn. z. 6, w. 76, t. 1088, E. Szczucki do konsula generalnego RP w Brukseli [7 III 1947 r.], k. 25. Pisownia oryginalna.

${ }_{45}$ AMSZ, DP, sygn. z. 6, w. 76, t. 1088, Konsulat RP w Luksemburgu do poselstwa RP w Brukseli [3 III 1948 r.], k. 28. 
przyjąć, że powroty Polaków do kraju z Luksemburga po 1947 r. albo nie miały miejsca, albo były jednostkowe. M. Kiełczewska-Zaleska i A. Bonasewicz podają, że w 1947 r. mieszkało w Luksemburgu nadal jeszcze 1314 obywateli polskich, z których większość stanowiła przedwojenna emigracja zarobkowa ${ }^{46}$.

Na koniec warto nadmienić kilka słów na temat repatriacji Luksemburczyków z Polski po II wojnie światowej. Już na początku wymiany ludności strona luksemburska natrafiła na przeszkody w repatriacji swych obywateli. Sprawa była na tyle poważna, że szef luksemburskiej Misji Repatriacyjnej w Polsce kpt. Antoine Hirsch musiał interweniować u płk. Andrzejewskiego, dyrektora gabinetu w Ministerstwie Bezpieczeństwa Publicznego. W swym piśmie wyjaśniał, ze w trakcie wojny Niemcy wywieźli z Luksemburga ok. 35 tys. jego obywateli, a pod koniec wojny przymusowo zmobilizowali młodzież z roczników 1920-1928 do Wehrmachtu.

Po zakończeniu wojny okazało się, że w Europie Wschodniej znajduje się ok. 3 tys. Luksemburczyków w obozach jenieckich lub pracy. Pewna ich bliżej nieokreślona liczba miała się znajdować na terenie Polski, a konkretnie w kopalniach Górnego Śląska. Ponieważ nie posiadali oni żadnych dokumentów tożsamości, władze polskie nie były świadome ich narodowości i traktowały ich jak niemieckich jeńców. Szef luksemburskiej Misji Repatriacyjnej A. Hirsch zwracał się z prośbą o możliwość wejścia do obozów jenieckich i ustalenie, czy nie znajdują się tam obywatele Luksemburga, co było zgodne z literą układu z 24 września ${ }^{47}$.

Brak odnośnych dokumentów co do reakcji płk. Andrzejewskiego na prośbę kpt. A. Hirscha. Przypuścić należy jednak, że prawdopodobnie wydano zgodę na lustrację, ale tylko wybranych obozów jenieckich na terenie Górnego Śląska. Okazało się jednak, że nie rozwiązało to sprawy i rok później szef luksemburskiej Misji Repatriacyjnej musiał ponownie interweniować. Tym razem zwracał się z prośbą, zarówno do polskiego MSZ, jak i bezpośrednio do płk. Andrzejewskiego z MBP, o zgodę na wejście do obozów jenieckich na terenie Polski. Według słów Luksemburczyka, w obozie w Białej Podlaskiej miało się znajdować 78 Luksemburczyków, z tego 56 stanowili jeńcy siłą wcieleni do Wehrmachtu. Ponadto kolejne 4 osoby miały znajdować się w Bydgoszczy, ok. 10 w Katowicach i bliżej nieokreślona liczba w Opolu i Wrocławiu. Świadczyć to może o dużej determinacji przedstawiciela Luksemburga w repatriowaniu swych współobywateli ${ }^{48}$.

Strona luksemburska nie tylko była zainteresowana repatriacją swych obywateli żyjących na terenie całej Polski, ale także pragnęła sprowadzić ciała rodaków, którzy

${ }^{46}$ M. Kiełczewska-Zaleska, A. Bonasewicz (1960), Rozmieszczenie Polaków zagranicą, „Problemy Polonii Zagranicznej", t. 1, s. 9; J. Wróbel, op. cit., s. 483.

${ }_{47}$ AMSZ, DP, sygn. z. 6, w. 76, t. 1088, Kpt. A. Hirsch do ptk. Andrzejewskiego [12 X 1945 r.], k. 12-13.

${ }^{48}$ AMSZ, DP, sygn. z. 6, w. 76, t. 1088, Raport sur la présence de ressortissants luxembourgeois sur le territoire polonais [24 X 1946 r.], k. 6-7; ibidem, Kpt. A. Hirsch do Wydziału Europy Pótnocnej i Zachodniej MSZ [5 XI 1946 r.], k. 9. 
zginęli i zostali pochowani w Polsce ${ }^{49}$. Warszawa wyraziła na to zgodę i niebawem z Luksemburga wyruszył konwój samochodowy do Polski. To właśnie tym transportem zamierzano przerzucić do kraju część Polaków przebywających do tej pory w Luksemburgu. O wynikach tych zamierzeń była już mowa.

Ministerstwo Bezpieczeństwa Publicznego wolało jednak samo przeprowadzić lustrację obozów jenieckich pod kątem ewentualnej obecności w nich obywateli Luksemburga. W dniu 21 I 1947 r. przekazano MSZ nazwiska trzech Luksemburczyków: Mathiasa Poescha, Hansa Baumgartena oraz Karla Tussela, którzy przebywali w Polsce, w charakterze jeńców wojennych. Poinformowano, że zostaną oni przetransportowani do Warszawy, a następnie przekazani luksemburskiej Misji Repatriacyjnej ${ }^{50}$.

Historiografia polska może się poszczycić licznymi pracami z zakresu repatriacji rodaków po II wojnie światowej. Pierwsze prace powstawały już w czasach PRL, z czego najbardziej znane to dzieła Krystyny Kersten czy Stefana Banasiaka. Ponadto ukazywały się liczne artykuły naukowe lub popularnonaukowe. Temat ten był jednak traktowany po macoszemu i to mimo dużego ciężaru gatunkowego, sprawa bowiem dotyczyła ogromnych mas ludzi. Zwrot w kierunku badań nad tym zagadnieniem nastąpił po 1989 r., kiedy to powstała możliwość badań źródeł archiwalnych oraz ułatwiono dostęp do literatury zagranicznej. Z tego okresu pochodzą prace Czesława Łuczaka czy Andrzeja Pilcha. Ostatnią pracą, która bardzo poszerzyła stan badań nad repatriacją Polaków z Zachodu, jest opracowanie Janusza Wróbla. Jednak dla większości badaczy temat ten był jedynie pobocznym zagadnieniem.

Mimo tych licznych prac, zarówno o charakterze syntetycznym, jak i monografii, wciąż pozostaje wiele niezbadanych wątków dotyczących powrotu Polaków z Europy Zachodniej do kraju. Takim przypadkiem była do tej pory kwestia repatriacji z Luksemburga. Powojenna migracja rodaków z tego kraju stanowiła zaledwie epizod w całej epopei powrotu Polaków z Europy Zachodniej. Świadczy o tym przede wszystkim znikoma liczba repatriantów, jaką udało się ustalić autorowi. Z dużą dozą pewności można przyjąć, że odsetek ten w rzeczywistości był większy, jednak nie ma żadnego odzwierciedlenia w materiale źródłowym. Mimo wszystko trudno jest zestawiać liczbę powrotów z Luksemburga z takimi krajami, jak Niemcy, Francja, Szwajcaria, Wielka Brytania czy nawet Belgia lub Holandia. Skupiska Polaków w tych krajach były wielokrotnie większe, co wynikało z rozmaitych zawirowań dziejowych. Nie można jednak przyjąć liczb za jedyne kryterium $\mathrm{w}$ badaniu problemu powojennych ruchów ludnościowych. $\mathrm{Z}$ tego powodu autor postanowił wypełnić lukę w historiografii, zajmując się powyższą kwestią.

49 AMSZ, DP, sygn. z. 6, w. 76, t. 1088, Kpt. A Hirsch do Biura do Spraw Repatriacji MSZ w Warszawie [5 XII 1946 r.], k. 14.

50 AMSZ, DP, sygn. z. 6, w. 76, t. 1088, Kpt. A Hirsch do płk. Andrzejewskiego [5 XII 1946 r.], k. 15; ibidem, Płk. Andrzejewski do MSZ [21 I 1947 r.], k. 17. 
Opracowanie to poszerza dotychczasowy stan badań nad repatriacją Polaków z Europy Zachodniej i może być punktem wyjścia do dalszych szczegółowych analiz losów rodaków w tej części świata.

\section{Bibliografia}

Archiwum Akt Nowych, Generalny Pełnomocnik Rządu do spraw Repatriacji, Archiwum Akt Nowych, Ministerstwo Pracy i Opieki Społecznej w Londynie Archiwum Akt Nowych, Ministerstwo Przemysłu, Handlu i Żeglugi w Londynie, Archiwum Akt Nowych, Ministerstwo Spraw Zagranicznych w Warszawie, Archiwum Ministerstwa Spraw Zagranicznych, Departament Polityczny 1945-1948,

Basiński E. (1971), Polonia solidarna z Macierza. Z dziejów wychodźstwa polskiego, Warszawa: Ludowa Spółdzielnia Wydawnicza.

Eder W. (1988), Z dziejów wychodźstwa polskiego do Luksemburga, „Przegląd Polonijny”, z. 4. Eder W. (1992), Polonia w krajach Beneluksu. Luksemburg, w: Szydłowska-Ceglowa B. (red.), Polonia w Europie, Poznań: Polska Akademia Nauk, Zakład Badań Narodowościowych.

Janowska H. (1981), Emigracja zarobkowa z Polski 1918-1938, Warszawa: Państwowe Wydawnictwo Naukowe.

Kersten K. (1974), Repatriacja ludności polskiej po II wojnie światowej. Studium historyczne, Wrocław: Zakład Narodowy im. Ossolińskich, Wydawnictwo PAN.

Kiełczewska-Zaleska M., Bonasewicz A. (1960), Rozmieszczenie Polaków zagranicą, „Problemy Polonii Zagranicznej", t. 1.

Loesch F. (1937), Emigracja polska w Wielkim Księstwie Luksemburskim, „Polacy Zagranicą", nr 11.

Łuczak Cz. (1979), Polityka ludnościowa i ekonomiczna hitlerowskich Niemiec w okupowanej Polsce, Poznań: Wydawnictwo Poznańskie.

Nadolny A. (1984), Polonia w Luksemburgu (1918-1985), „Studia Polonijne”, t. VIII.

Podpisanie umowy repatriacyjnej polsko-luksemburskiej, „Głos Ludu” (1945), nr 253.

Polskie misje repatriacyjne pracują na terenie Europy Zachodniej, „Głos Ludu” (1945), nr 274.

Sula D. (2002), Działalność przesiedleńczo-repatriacyjna Państwowego Urzędu Repatriacyjnego w latach 1944-1951, Lublin: Wydawnictwo Katolickiego Uniwersytetu Lubelskiego.

Wierzbiański B. (1946), Polacy w świecie, Londyn: Światpol.

Wierzbiański B. (1946), Polonia zagraniczna w latach 1939-1946, Londyn: Światowy Związek Polaków z Zagranicy.

Wróbel J. (2009), Na rozdrożu historii. Repatriacja obywateli polskich z Zachodu w latach 1945 -1949, Łódź: Instytut Pamięci Narodowej.

Zabraniak S. (2006), Polacy w Luksemburgu. Imigracja i duszpasterstwo w XX wieku, „Studia Polonijne”, t. 27. 